P-ISSN: 2615-1723

E-ISSN: 2615-1766

April 2020
Jurnal Riset Pendidikan Dasar

03 (1), (2020) 87-96

Submitted: Maret, Accepted: Maret, Published: April

\title{
PERSEPSI GURU TERHADAP APLIKASI EDMODO SEBAGAI ALAT BANTU KEGIATAN BELAJAR DI SEKOLAH DASAR
}

\author{
Novita Wisudawati ${ }^{1}$, Eko Kuntarto ${ }^{2}$, Agung Rimba Kurniawan ${ }^{3}$ \\ 1,2,3 Prodi Pendidikan Guru Sekolah Dasar, Fakultas Keguruan dan Ilmu Pendidikan, \\ Universitas Jambi, Indonesia
}

Korespondensi.E-mail: novitawisudawati62@gmail.com

\begin{abstract}
Abstrak
Penelitian ini bertujuan untuk mendeskripsikan persepsi guru terhadap aplikasi edmodo sebagai alat bantu kegiatan belajar di SD Islam Al-Falah Jambi. Peneliti memilih SD Islam Al-Falah Jambi sebagai tempat dilaksanakannya penelitian karena sekolah ini merupakan salah satu sekolah yang telah menerapkan pembelajaran dalam jaringan (daring), salah satunya menggunakan aplikasi edmodo. Penelitian ini menggunakan desain penelitian deskriptif kuantitatif untuk mengukur persepsi guru terhadap aplikasi edmodo sebagai alat bantu kegiatan belajar dengan mendeskripsikan data hasil penyebaran kuesioner yang bersifat kuantitatif. Teknik pengumpulan data pada penelitian ini menggunakan kuesioner yang diberikan kepada sembilan guru kelas. Peneliti memilih teknik sampelbertujuan, dikarenakan pada penelitian ini peneliti menetapkan responden dengan ciri khusus yaitu guru yang menggunakan aplikasi edmodo. Sebelum dibagikan kuesioner, peneliti melakukanvalidasi kuesioner dengan menggunakan validasi isi. Teknik analisis data pada penelitian ini menggunakan analisis statistik deskriptif.Hasil penelitian ini menunjukkan bahwa persepsi guru terhadap aplikasi edmodo sebagai alat bantu kegiatan belajar di SD Islam Al-Falah Jambi, pada indikator kemudahan penggunaan diperoleh persentase rata-rata sebesar $84,02 \%$ dengan kriteria baik, indikator pengelolaan penggunaan diperoleh persentase rata-rata sebesar $80,55 \%$ dengan kriteria baik, indikator penyajian informasi diperoleh persentase rata-rata $78,78 \%$ dengan kriteria baik, pada indikator kecepatan akses pada aplikasi diperoleh persentase rata-rata sebesar $79,16 \%$ dengan kriteria baik, indikator kepuasan penggunaan diperoleh persentase rata-rata sebesar $84,72 \%$ pada kriteria baik. Persepsi guru terhadap aplikasi edmodo sebagai alat bantu kegiatan belajar dari lima indikator diperoleh persentase rata-rata $81,451 \%$, sehingga dapat disimpulkan bahwa persepsi guru terhadap aplikasi edmodo sebagai alat bantu kegiatan belajar di SD Islam Al-Falah Jambi dikategorikan baik.
\end{abstract}

Kata Kunci:Persepsi Guru;Aplikasi Edmodo; Alat Bantu Kegiatan Belajar

\section{TEACHER'S PERCEPTION OF THE APPLICATION OF EDMODO AS A TOOL FOR LEARNING ACTIVITIES IN ELEMENTARY SCHOOL}

\begin{abstract}
This study aims to describe teachers' perceptions of the application of edmodo as a tool for learning activities in AlFalah Jambi Islamic Elementary School. Researchers chose the Al-Falah Jambi Islamic Elementary School as a place to conduct research because this school is one of the schools that has implemented online learning, one of which uses the Edmodo application. This study uses a descriptive quantitative research design to measure teachers' perceptions of edmodo applications as a learning aid tool by describing quantitative questionnaire data. Data collection techniques in this study used a questionnaire given to nine class teachers. The researcher chose the purposive sample technique, because in this study the researcher assigned respondents with a special characteristic, namely the teacher who used the Edmodo application. Before the questionnaire was distributed, the researcher conducted a questionnaire validation using content validation. Data analysis techniques in this study used descriptive statistical analysis. The results of this
\end{abstract}

Copyright $\mathbb{0} 2020$, JRPD, ISSN 2615 - 1723 (Print), ISSN 2615 - 1766 (Online) 
study indicate that teachers' perceptions of the application of Edmodo as a learning aid tool in the Islamic Elementary School Al-Falah Jambi, the easy of use indicators obtained an average percentage of $84.02 \%$ with good criteria, indicators of cuztomization obtained an average percentage of $80.55 \%$ with good criteria, the indicator of content obtained an average percentage of $78.78 \%$ with good criteria, the indicator of download delay obtained an average percentage of $79.16 \%$ with good criteria, an indicator of user satisfaction obtained an average percentage average of $84.72 \%$ in good criteria. Teachers 'perceptions of edmodo applications as learning aids of the five indicators obtained an average percentage of $81.451 \%$, so it can be concluded that teachers' perceptions of edmodo applications as aids to learning activities in Al-Falah Jambi Islamic Elementary School are categorized as good.

Keywords:Teacher Perception; Edmodo Aplication; Learning Aids

\section{PENDAHULUAN}

Abad 21 memiliki perkembangan yang ditandai dengan perubahan tata kehidupan yang berbeda dengan kehidupan sebelumnya. Salah satu perubahan terdapat pada karakter masyarakat abad 21 yang berimplikasi terhadap karakter guru. Menurut (Kanca, 2018: 22) "perubahan yang terjadi di masyarakat diikuti dengan transformasi budaya (kultur) guru dalam pembelajaran". Apabila masyarakat telah berubah menjadi masyarakat era digital, maka guru harus mengalihkan diri secara sosio-kultural maupun teknik.

Pembelajaran dilaksanakan oleh guru dengan mengikuti era digital yang terjadi di masyarakat merupakan bagian dari karakteristik guru pada abad 21. Menurut Kanca, guru abad 21 memiliki karakteristik salah satunya yaitu harus mampu beralih pada era digitaliasasi dan harus kreatif serta inovatif dalam mengembangkan strategi/ model/ metode belajar sehingga dapat meningkatkan kualitas dalam pembelajaran menggunakan TIK (Kanca, 2018: 22).

Teknologi dalam pembelajaran berdampak positif sebagai penunjang pembelajaran. Seorang guru dapat memanfaatkan kecanggihan teknologi yang dapat dijadikan sebagai alat bantu atau media kegiatan belajar di sekolah. "Kompetensi pedagogik guru berdasarkan Permendiknas No. 16 Tahun 2007 tentang standar kualifikasi akademik dan kompetensi guru menyatakan bahwa salah satu kompetensi pedagogik guru adalah memanfaatkan kecanggihan teknologi, informasi, dan komunikasi sebagai kepentingan pembelajaran" (Sukono, 2018: 6061).

Pembelajaran di SD dapat dilaksanakan dengan Pembelajaran Jarak Jauh (PJJ) sehingga peserta didik dapat memanfaatkan kecanggihan TIK sebagai mediaatau alat bantu kegiatan belajar. Permendikbud No. 119 Tahun 2014 tentang Penyelenggaraan Pendidikan Jarak Jauh di Jenjang Pendidikan Dasar dan Menengahdijelaskan pada pasal 5 ayat 1 menyatakan bahwa "pendidikan jarak jauh dengan lingkup mata pelajaran diselenggarakan oleh SD/MI, SMP/MTs, SMA/MA, SMK/SMAK reguler" (Permendikbud, 2014: 5).Pembelajaran jarak jauh membutuhkan media pembelajaran. Media pembelajaran dapat dimanfaatkan sebagai alat bantu belajar yang dapat diakses kapan saja, dan dimana saja dalam jaringan (daring), salah satunya dapat menggunakan aplikasi edmodo sebagai sarananya.

Edmodo merupakan alat bantu belajar yang dapat dimanfaatkan oleh guru dan juga peserta didik. Pengertian edmodo menurut Basori yaitu edmodo merupakansuatu platformmicroblogging yang dibuat khususuntuk dikembangkan dan dirancang khusus bagi guru dan peserta didik dengan aman dan mudah, sehingga dapat berkomunikasi dan berkolaborasi untuk berbagi konten berupa video, gambar, link, teks, dan audio (Basori, 2013: 100).

Edmodo banyak bermanfaat dalam dunia pendidikan. Hal ini sejalan dengan penelitian yang dilakukan oleh Dewi Hastaty Lanusi pada tahun 2018 dengan judul 
"Penerapan Kelas Digital Edmodo untuk Meningkatkan Minat Belajar dan Hasil Belajar Siswa SD Negeri No. 86 Kota Gorontalo". Hasil penelitian tersebut menunjukkan bahwa penerapan kelas digital edmodo dapat meningkatkan minat belajar dan hasil belajar siswa, dibuktikan dengan meningkatnya minat belajar dari $50 \%$ menjadi $78,5 \%$ sedangkan hasil belajar dari nilai rata-rata 72 menjadi 88 . Hal ini membuktikan bahwa edmodo dapat meningkatkan minat dan hasil belajar peserta didik (Lanusi, 2018).

Keterbaruan dari penelitian terdahulu dengan penelitian peneliti adalah apabila penelitian terdahulu mampu menunjukkan bahwa dengan penerapan kelas digital edmodo dapat meningkatkan minat dan hasil belajar peserta didik SD, maka dengan diterapkannya aplikasi edmodo sebagai salah satu pembelajaran daring, sehingga peneliti ingin mengetahui persepsi guru SD terhadap aplikasi edmodo di SD.

Peneliti melakukan observasi dan wawancara di SD Islam Al-Falah Jambi, peneliti mengamati pembelajaran yang dilaksanakan hampir seluruhnya telah memanfaatkan kecanggihan TIK. Adanya tuntutan dari sekolah berkaitan dengan pengguasaan TIK sebagai pembelajaran daring, banyak guru-guru yang mengikuti pelatihan pembelajaran daring. Aplikasi edmodo telah disosialisasikan oleh salah satu guru yang mengikuti pelatihan VICON di SEAMOLEC kemudian diadakan workshop untuk mengenalkan aplikasi edmodo sebagai salah satu pembelajaran daring di SD Islam Al-Falah Jambi, dari workshop tersebut guru yang mengikuti pelatihan VICON di SEAMOLEC menjadi narasumber dan guruguru lain menjadi pesertanya. Sehingga aplikasi edmodo menjadi sarana pembelajaran daring (pembelajaran dalam jaringan) di SD Islam Al-Falah Jambi.

Berdasarkan hal tersebut, peneliti ingin mengetahui pandangan guru terkait penggunaan aplikasi edmodo di sekolah dasar, untuk itu peneliti melakukan penelitian dengan judul "Persepsi Guru Terhadap Aplikasi Edmodo sebagai Alat Bantu Kegiatan Belajar di Sekolah Dasar".

\section{METODE}

Penelitian ini dilaksanakan di SD Islam Al-Falah Jambi, pemilihan sekolah ini atas pertimbangan tertentu yakni sekolah yang telah menerapkan pembelajaran dalam jaringan (daring), salah satunya menggunakan aplikasi edmodo sebagai alat bantu kegiatan belajar. Desain penelitian ini menggunakan penelitian deskriptif kuantitatif.Penelitian deskriptif pada penelitian ini bertujuan untuk mengukur persepsi guru terhadap aplikasi edmodo sebagai alat bantu kegiatan belajar di SD Islam Al-Falah Jambi dengan mendeskripsikan hasil penyebaran kuesioner persepsi guru dari data yang bersifat kuantitatif. Data dari hasil penyebaran kuesioner penelitian ini berupa angka-angka hasil perhitungan yang diolah melalui pengklasifikasian, penjumlahan, mencari ratarata, kemudian diperoleh persentase yang disesuaikan dengan indikator yang telah ditetapkan.

Populasi pada penelitian ini adalah guru kelas SD Islam Al-Falah Jambi yang terdiri dari 24 guru. Dari keseluruhan populasi tersebut, peneliti mengambil 9 orang guru sebagai sampel dengan 1 guru laki-laki dan 8 guru perempuan. Peneliti memilih teknik sampel purposive sampling dikarenakan peneliti menetapkan ciri khusus yaitu guru yang menggunakan aplikasi edmodo. Menurut Sugiyono "Purposive sampling merupakan teknik yang digunakan dengan pertimbangan tertentu dalam pengambilan sumber data, peneliti mempunyai ciri khusus yang ditetapkan sesuai dengan tujuan penelitian" (Sugiyono, 2015: 300).

Peneliti menggunakan teknik pengumpulan data dengan kuesioner. Kuesioner menurut (Sugiyono, 2014: 199) menyatakan bahwa kuesioner adalah suatu teknik pengumpulan data yang diperoleh Copyright (C2020, JRPD, ISSN 2615 - 1723 (Print), ISSN 2615 - 1766 (Online) 
dengan cara memberikan seperangkat pernyataan atau pertanyaan tertulis kepada informan untuk dijawab". Selain itu, menurut Cristensen (Sugiyono, 2013: 71) "peneliti dapat memilih kuesioner untuk mendapatkan data berkaitan dengan perasaaan, kepercayaan, kepribadian, nilai, persepsi, perilaku dari informan". Pengumpulan data menggunakan kuesioner merupakan teknik yang efisien.Adapun langkah-langkah dalam mengumpulkan data penelitian ini sebagai berikut:

1. Menemui setiap subjek penelitian sesuai dengan jumlah yang telah ditetapkan.

2. Memberikan penjelasan mengenai persepsi secara umum.

3. Melakukan penyebaran kuesioner kepada seluruh subjek penelitian.

4. Memberikan penjelasan mengenai petunjuk pengisian kuesioner.

5. Masing-masing subjek penelitian mengisi kuesioner yang dibagikan oleh peneliti.

6. Peneliti mengambil lembar jawaban kuesioner yang telah diisi oleh subjek penelitian.

Sebelum instrumen penelitian dibagikan peneliti melakukan validitas,pada penelitian ini peneliti menggunakan teknik validitas isi. Data yang diperoleh dalam penelitian ini bersumber dari hasil penyebaran kuesioner kepada 9 guru di SD Islam Al-Falah Jambi. Setelah data terkumpul, maka peneliti akan menganalisis data menggunakan teknik analisis deskriptif statistik.

\section{HASIL DAN PEMBAHASAN}

Penelitian ini dilaksanakan di SD Islam Al-Falah Jambi dengan subjek penelitian yang berjumlah 9 guru kelas terdiri dari 1 guru lakilaki dan 8 guru perempuan. Penelitian ini dilakukan pada tanggal 06 Januari s.d 15 Februari 2020. Pengumpulan data pada penelitian ini menggunakan kuesioner. Kuesioner yang digunakan dalam penelitian ini berbentuk kuesioner tertutup yang sudah disediakan jawaban oleh peneliti. Kuesioner penelitian ini terdiri dari 20 item pertanyaan dengan kriteria jawaban berdasarkan modifikasi skala likert yang meliputi SS mempunyai skor 4 , S mempunyai skor 3 , TS mempunyai skor 2, dan STS mempunyai skor 1.

Pertanyaan pada kuesioner terdiri beberapa indikator diantaranya meliputi kemudahan penggunaan (easy of use) yang terdiri dari 4 pertanyaan, pengelolaan penggunaan (cuztomization) terdiri dari 1 soal, penyajian informasi (content) yang terdiri dari 11 pertanyaan, kecepatan akses pada aplikasi (download delay) yang terdiri dari 2 pertanyaan, dan kepuasan penggunaan (user satisfaction) yang terdiri dari 2 pertanyaan. Maka penyajian data dalam penelitian ini terdiri dari 5 indikator persepsi guru terhadap aplikasi edmodo sebagai alat bantu kegiatan belajar di SD Islam Al-Falah Jambi.

\section{Data Persepsi Guru Ditinjau dari Indikator Kemudahan Penggunaan (Easy of Use)}

Kemudahan penggunaan yang dimaksud pada penelitian ini yaitu kemudahan guru dalam menggunakan aplikasi edmodo sebagai alat bantu kegiatan belajar. Berdasarkan analisis data dari lembar kuesioner dari jawaban guru pada indikator kemudahan penggunaan (easy of use), diperoleh data mengenai guru yang menjawab sangat setuju dan setuju.Pada indikator kemudahan penggunaan (easy of use), persentase terendah dari jawaban guru dengan persentase $75 \%$ berada pada kriteria B (baik). Adapun persentase tertinggi dari jawaban guru dengan persentase $100 \%$ berada pada kriteria SB (sangat baik). Selain itu 5 orang guru memperoleh persentase $81,25 \%$ dengan kriteria B (baik), dan 2 orang guru memperoleh persentase $87,5 \%$ dengan kriteria B (baik).Adapun persentase rata-rata yang diperoleh guru pada indikator kemudahan penggunaan (easy of use) secara klasikal adalah sebesar $84,02 \%$ pada kriteria baik. Dengan demikian, guru SD Islam Al-Falah Jambi mempunyai persepsi baik pada indikator kemudahan penggunaan (easy of use).

Copyright (C2020, JRPD, ISSN 2615 - 1723 (Print), ISSN 2615 - 1766 (Online) 
Jurnal Riset Pendidikan Dasar, 03 (1), April 2020 (87-96)

Novita Wisudawati, Eko Kuntarto, Agung Rimba Kurniawan

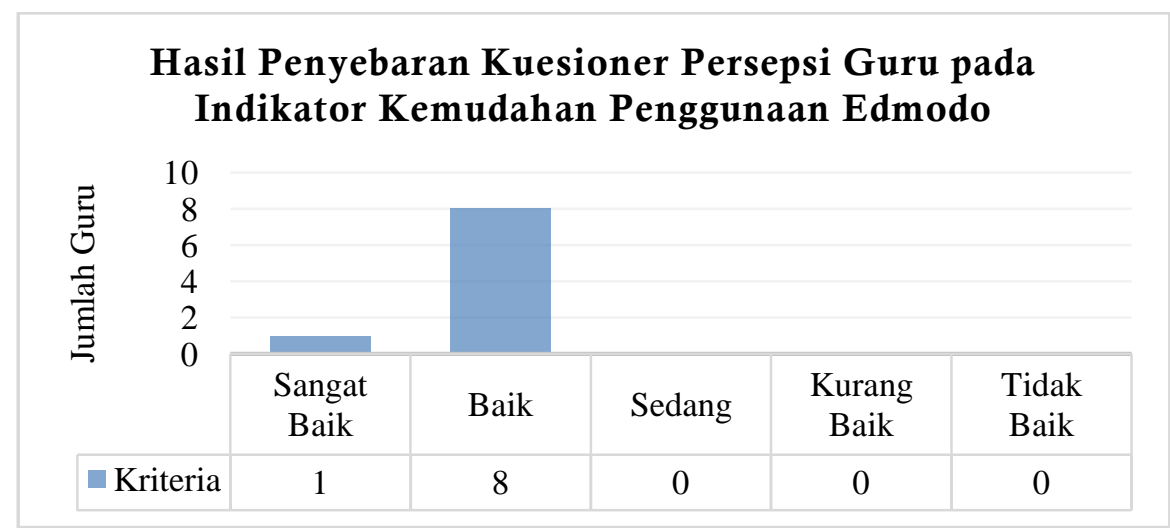

Gambar 1 Grafik Penskoran Indikator Kemudahan Penggunaan (Easy of Use)

\section{Data Persepsi Guru Ditinjau dari Indikator Pengelolaan Penggunaan (Cuztomization)}

Pengelolaan penggunaan pada aplikasi edmodo yaitu mengenai kesesuaian dari keberagaman fitur-fitur yang terdapat pada aplikasi edmodo dengan kebutuhan pembelajaran.Berdasarkan analisis data dari lembar kuesioner jawaban guru pada indikator pengelolaan penggunaan(cuztomization), diperoleh data mengenai persepsi guru yang menjawab sangat setuju dan setuju. Pada indikator penggunaan(cuztomization), terendah dari jawaban guru dengan persentase $75 \%$ berjumlah 7 orang guru berada pada kriteria B (baik). Adapun persentase tertinggi dari jawaban guru dengan persentase $100 \%$ berjumlah 2 orang guru berada pada kriteria SB (sangat baik). Adapun persentase rata-rata yang diperoleh guru pada indikator pengelolaan penggunaan(cuztomization) secara klasikal adalah sebesar $80,55 \%$ pada kriteria baik. Dengan demikian, guru SD Islam AlFalah Jambi mempunyai persepsi baik pada indikator pengelolaan penggunaan(cuztomization).

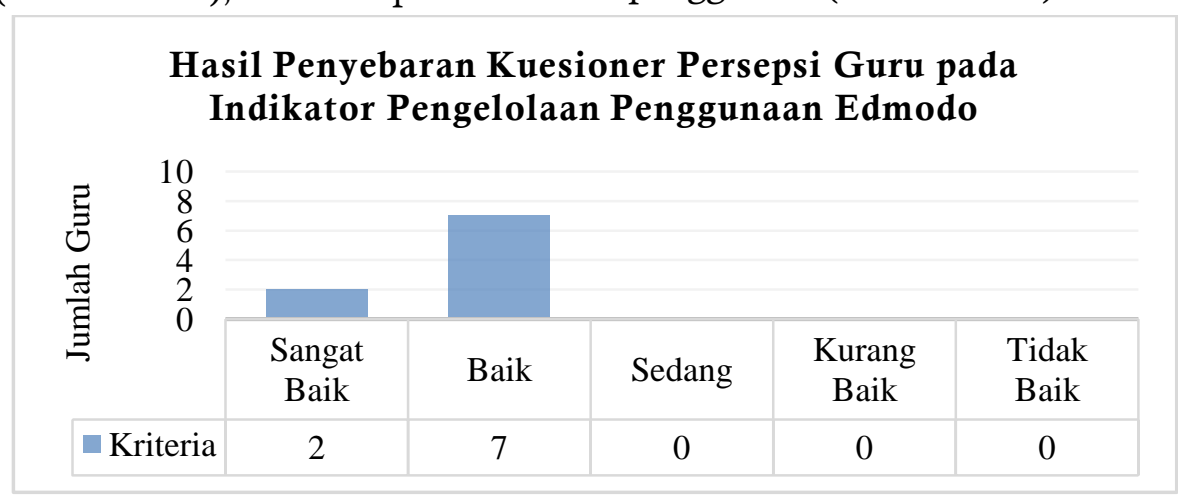

Gambar 2 Grafik Penskoran Indikator Pengelolaan Penggunaan (Cuztomization)

Data Persepsi Guru Ditinjau dari Indikator Penyajian Informasi (Content)

Penyajian informasi yang dimaksud pada penelitian ini yaitu adanya keberagaman fiturfitur pada aplikasi edmodo untuk kebutuhan pembelajaran. Berdasarkan analisis data dari lembar kuesioner jawaban guru pada indikator penyajian informasi (content), diperoleh data mengenai guru yang menjawab sangat setuju, setuju dan tidak setuju. Pada indikator penyajian informasi (content), persentase terendah dari jawaban guru dengan persentase $70,45 \%$ berjumlah 1 orang guru berada pada kriteria B (baik). Adapun persentase tertinggi dari jawaban guru dengan persentase $84,09 \%$ berjumlah 3 orang guru berada pada kriteria (baik). Selain itu 1 orang guru memperoleh persentase $81,81 \%$ dengan kriteria B (baik), 1 orang guru memperoleh persentase $75 \%$ dengan kriteria B (baik), 1 orang guru

Copyright (C2020, JRPD, ISSN 2615 - 1723 (Print), ISSN 2615 - 1766 (Online) 
memperoleh persentase $72,72 \%$ dengan kriteria B (baik), 1 orang guru memperoleh persentase $77,27 \%$ dengan kriteria B (baik) dan 1 orang guru memperoleh persentase $79,54 \%$ dengan kriteria B (baik).Adapun persentase rata-rata yang diperoleh guru pada indikator penyajian informasi (content), secara klasikal adalah sebesar 78,78\% pada kriteria baik. Dengan demikian, guru SD Islam Al-Falah Jambi mempunyai persepsi baik pada indikator penyajian informasi (content).

\section{Hasil Penyebaran Kuesioner Persepsi Guru pada Indikator Penyajian Informasi pada Edmodo}

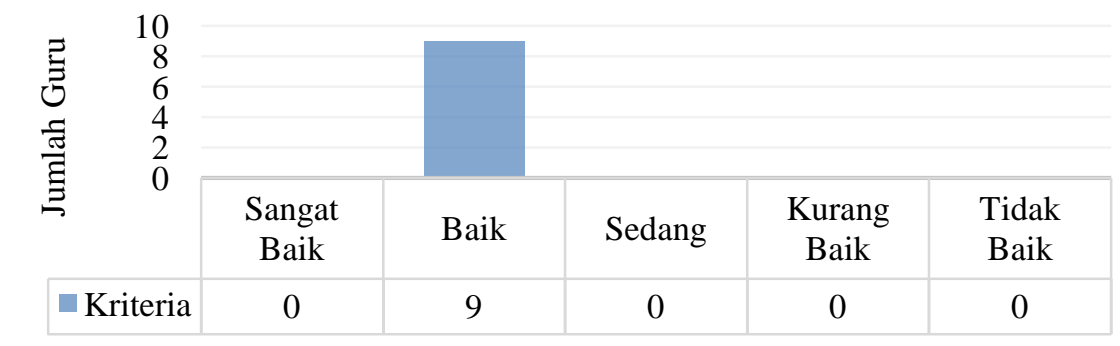

Gambar 3 Grafik Penskoran Indikator penyajian informasi (Content)

Data Persepsi Guru Ditinjau dari Indikator Kecepatan Akses pada Aplikasi Edmodo (Download Delay)

Kecepatan akses pada aplikasi emodo yaitu persepsi guru dalam mengakses aplikasi edmodo dengan mudah.Berdasarkan analisis data dari lembar kuesioner jawaban guru pada indikator kecepatan akses pada aplikasi (download delay), diperoleh data mengenai guru yang menjawab sangat setuju, dan setuju. Pada indikator kecepatan akses pada aplikasi (download delay), persentase terendah dari jawaban guru dengan persentase $75 \%$ berada pada kriteria B (baik) yang berjumlah 6 orang guru. Adapun persentase tertinggi dari jawaban guru dengan persentase $87,5 \%$ berada pada kriteria B (baik) berjumlah 3 orang guru.Adapun persentase rata-rata yang diperoleh guru pada indikator kecepatan akses pada aplikasi (download delay) secara klasikal adalah sebesar $79,16 \%$ pada kriteria baik. Dengan demikian, guru SD Islam Al-Falah Jambi mempunyai persepsi baik pada indikator kecepatan akses pada aplikasi (download delay).

\section{Hasil Penyebaran Kuesioner Persepsi Guru pada Indikator Kecepatan Akses pada Aplikasi Edmodo}

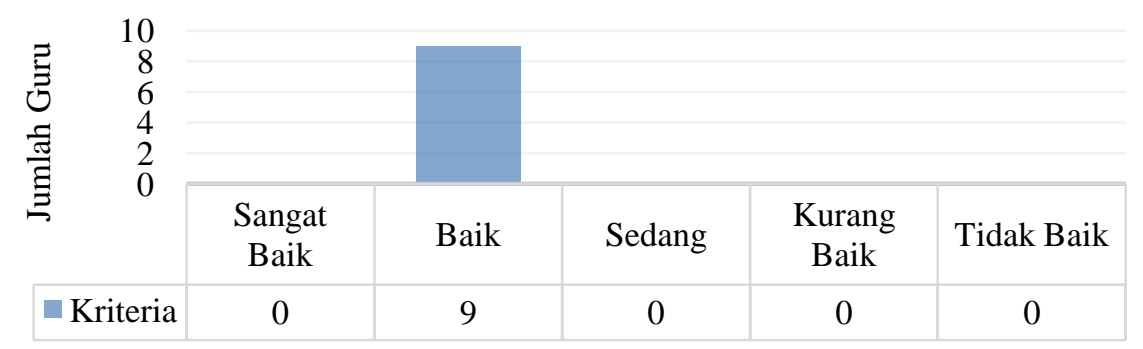

Gambar 4 Grafik Penskoran Indikator Kecepatan Akses pada Aplikasi (Download Delay)

Data Persepsi Guru Ditinjau dari Indikator Kepuasan Penggunaan (User Satisfaction)

Kepuasan penggunaan (user satisfaction) pada aplikasi edmodo yaitu mengenai persepsi guru pada kepuasan dalam menggunakan aplikasi edmodo sebagai alat bantu kegiatan belajar. Berdasarkan analisis data dari lembar kuesioner jawaban guru pada indikator

Copyright (C2020, JRPD, ISSN 2615 - 1723 (Print), ISSN 2615 - 1766 (Online) 
kepuasan penggunaan (user satisfaction), diperoleh data mengenai guru yang menjawab sangat setuju dan setujuPada indikator kecepatan akses pada aplikasi (download delay), persentase terendah dari jawaban guru dengan persentase $75 \%$ berada pada kriteria B (baik) yang berjumlah 4 orang guru. Adapun persentase tertinggi dari jawaban guru dengan persentase $100 \%$ berada pada kriteria SB (sangat baik) berjumlah 2 orang guru. Selain itu 3 orang guru memperoleh persentase $87,5 \%$ dengan kriteria B (baik).Adapun persentase rata-rata yang diperoleh guru pada indikator kepuasan penggunaan (user satisfaction) secara klasikal adalah sebesar $84,72 \%$ pada kriteria baik. Dengan demikian, guru SD Islam AlFalah Jambi mempunyai persepsi baik pada indikator kepuasan penggunaan (user satisfaction).

\section{Hasil Penyebaran Kuesioner Persepsi Guru pada Indikator Kepuasan Penggunaan Aplikasi Edmodo}

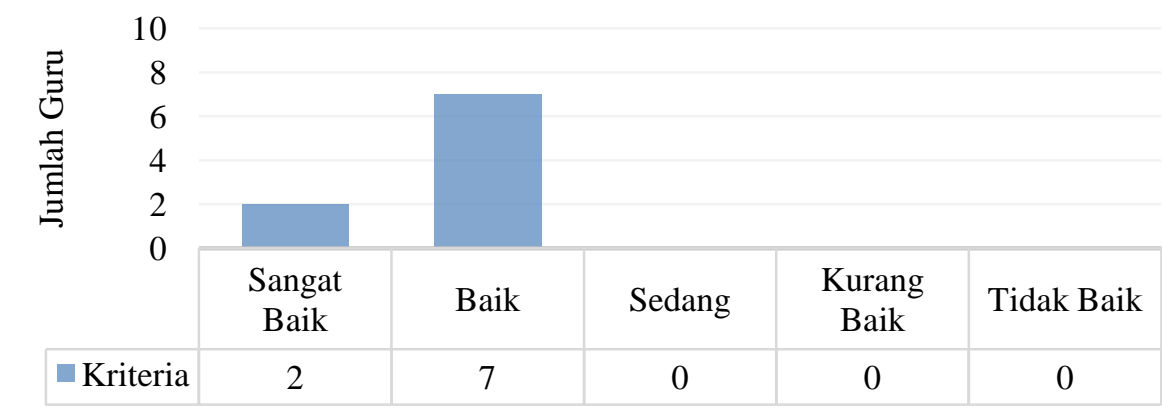

Gambar 5 Grafik Penskoran Indikator Kepuasan Penggunaan Aplikasi (User Satisfaction)

\section{Persepsi Guru Terhadap Aplikasi Edmodo}

Berdasarkan data hasil penyebaran kuesioner yang telah dipaparkan, maka dapat diketahui persepsi setiap guru terhadap aplikasi edmodo sebagai alat bantu kegiatan belajar di SD Islam Al-Falah Jambi berdasarkan rata-rata kelima indikator pada tabel berikut ini:

Tabel 1 Rekapitulasi Persepsi Guru Terhadap Aplikasi Edmodo sebagai Alat Bantu Kegiatan Belajar di SD Islam Al-Falah Jambi

\begin{tabular}{|c|c|c|c|c|c|c|c|c|c|}
\hline \multirow{2}{*}{ No. } & $\begin{array}{c}\text { Nama } \\
\text { Guru }\end{array}$ & $\begin{array}{c}\text { Kemudahan } \\
\text { Penggunaan }\end{array}$ & $\begin{array}{c}\text { Pengelolaan } \\
\text { Penggunaan }\end{array}$ & $\begin{array}{c}\text { Penyajian } \\
\text { Informasi }\end{array}$ & $\begin{array}{c}\text { Kecepatan } \\
\text { Akses }\end{array}$ & $\begin{array}{c}\text { Kepuasan } \\
\text { Penggunaan }\end{array}$ & $\begin{array}{c}\text { Jumlah } \\
\text { dalam } \\
\mathbf{( \% )}\end{array}$ & $\begin{array}{c}\text { Rata- } \\
\text { rata } \\
\text { dalam } \\
\text { (\%) }\end{array}$ & Kriteria \\
\hline 1. & LNYP & 100 & 100 & 81,81 & 87,5 & 100 & $\mathbf{4 6 9 , 3 1}$ & $\mathbf{9 3 , 8 6 2}$ & SB \\
\hline 2. & DY & 81,25 & 75 & 75 & 75 & 75 & $\mathbf{3 8 1 , 2 5}$ & $\mathbf{7 6 , 2 5}$ & B \\
\hline 3. & EA & 87,5 & 100 & 84,09 & 87,5 & 87,5 & $\mathbf{4 4 6 , 5 9}$ & $\mathbf{8 9 , 3 1 8}$ & SB \\
\hline 4. & IR & 81,25 & 75 & 70,45 & 87,5 & 75 & $\mathbf{3 8 9 , 2}$ & $\mathbf{7 7 , 8 4}$ & B \\
\hline 5. & ML & 87,5 & 75 & 72,72 & 75 & 75 & $\mathbf{3 8 5 , 2 2}$ & $\mathbf{7 7 , 0 4 4}$ & B \\
\hline 6. & RA & 81,25 & 75 & 77,27 & 75 & 75 & $\mathbf{3 8 3 , 5 2}$ & $\mathbf{7 6 , 7 0 4}$ & B \\
\hline 7. & AL & 81,25 & 75 & 79,54 & 75 & 87,5 & $\mathbf{3 9 8 , 2 9}$ & $\mathbf{7 9 , 6 5 8}$ & B \\
\hline 8. & RD & 75 & 75 & 84,09 & 75 & 87,5 & $\mathbf{3 9 6 , 5 9}$ & $\mathbf{7 9 , 3 1 8}$ & B \\
\hline 9. & WO & 81,25 & 75 & 84,09 & 75 & 100 & $\mathbf{4 1 5 , 3 4}$ & $\mathbf{8 3 , 0 6 8}$ & B \\
\hline \multicolumn{2}{|c|}{ Jumlah } & $\mathbf{7 5 6 , 2 5}$ & $\mathbf{7 2 5}$ & $\mathbf{7 0 9 , 0 6}$ & $\mathbf{7 1 2 , 5}$ & $\mathbf{7 6 2 , 5}$ & $\mathbf{3 6 6 5 , 3 1}$ & $\mathbf{7 3 3 , 0 6 2}$ & B \\
\hline \multicolumn{2}{l}{ Rata-rata } & $\mathbf{8 4 , 0 2}$ & $\mathbf{8 0 , 5 5}$ & $\mathbf{7 8 , 7 8}$ & $\mathbf{7 9 , 1 6}$ & $\mathbf{8 4 , 7 2}$ & & $\mathbf{8 1 , 4 5 1}$ & B \\
\hline
\end{tabular}

Persepsi guru terhadap aplikasi edmodo sebagai alat bantu kegiatan belajar di SD Islam Al-Falah Jambi, terdiri dari persepsi guru yang berada pada kriteria sangat baik diperoleh oleh 2 orang guru yang bernama LNYP dan EA. Guru yang mempunyai peserpsi pada kriteria

Copyright C2020, JRPD, ISSN 2615 - 1723 (Print), ISSN 2615 - 1766 (Online) 
baik diperoleh oleh 7 orang guru yang bernama DY, IR, ML, RA, AL, RD dan WO.

Berdasarkan rata-rata skor dari indikator persepsi guru terhadap aplikasi edmodo sebagai alat bantu kegiatan belajar di SD Islam Al-Falah Jambi yang disajikan dalam bentuk persentase berada pada kriteria baik dengan rata-rata persentase 81,451. Jadi dapat disimpulkan bahwa guru SD Islam Al-Falah Jambi berpandangan baik terhadap aplikasi edmodo sebagai alat bantu kegiatan belajar di sekolah dasar berdasarkan kelima indikator persepsi guru terhadap aplikasi edmodo pada penelitian yang dilakukan oleh peneliti.

\section{Hasil Penyebaran Kuesioner Persepsi Guru Terhadap Aplikasi Edmodo sebagai Alat Bantu Kegiatan Belajar di SD Islam Al-Falah Jambi}

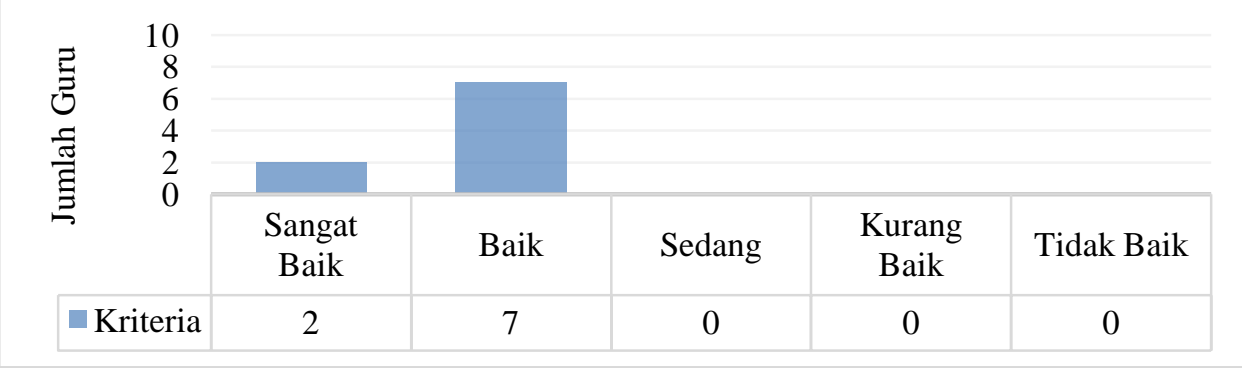

Gambar 6 Grafik Penskoran Persepsi Guru Terhadap Aplikasi Edmodo

\section{Pembahasan Hasil Analisis Data}

Pada pembahasan ini akan dibahas mengenai hasil analisis data yang telah dilakukan oleh peneliti. Adapun persepsi guru terhadap aplikasi edmodo sebagai alat bantu kegiatan belajar di SD Islam Al-Falah Jambi diperoleh dari penyebaran kuesioner yang disusun berdasarkan lima indikator persepsi mengenai aplikasi edmodo sebagai alat bantu kegiatan belajar. Peneliti melakukan penelitian dengan melakukan penyebaran kuesioner kepada 9 responden, kemudian peneliti mengambil lembar kuesioner yang telah diisi oleh responden. Setelah semua lembar kuesioner terkumpul, peneliti kemudian mengolah hasil penyebaran kuesioner secara kuantitatif dengan tujuan untuk memperoleh angka-angka pasti terkait persepsi guru terhadap aplikasi edmodo sebagai alat bantu kegiatan belajar berdasarkan kelima indikator.

Hasil penyebaran kuesioner persepsi guru terhadap aplikasi edmodo pada indikator kemudahan penggunaan (easy of use), persentase terendah dari persepsi guru yaitu sebesar $75 \%$ pada kriteria baik yang diperoleh oleh 1 orang guru. Persentase tertinggi dari persepsi guru yaitu sebesar $100 \%$ pada kriteria sangat baik oleh 1 orang guru. Selain itu, persepsi guru yang memperoleh persentase $81,25 \%$ pada kriteria baik sebanyak 5 orang guru, dan persepsi guru yang memperoleh persentase $87,5 \%$ pada kriteria baik sebanyak 2 orang guru. Rata-rata persentase yang diperoleh dari keseluruhan guru SD Islam AlFalah yang menjadi subjek penelitian berjumlah 9 orang guru pada indikator kemudahan penggunaan (easy of use) yaitu sebesar $84,02 \%$ pada kriteria baik. Dapat disimpulkan dari data yang diperoleh, rata-rata guru yang menjadi subjek penelitian di SD Islam Al-Falah Jambi berpandangan baik pada indikator kemudahan penggunaan (easy of use) pada aplikasi edmodo sebagai alat bantu kegiatan belajar.

Hasil penyebaran kuesioner persepsi guru terhadap aplikasi edmodo pada indikator pengelolaan penggunaan (customization), persentase terendah dari persepsi guru yaitu sebesar sebesar $75 \%$ pada kriteria baik yang diperoleh oleh 7 orang guru. Persentase tertinggi dari persepsi guru yaitu sebesar $100 \%$ pada kriteria sangat baik oleh 2 orang guru. Rata-rata persentase yang diperoleh dari keseluruhan guru SD Islam Al-Falah yang

Copyright C2020, JRPD, ISSN 2615 - 1723 (Print), ISSN 2615 - 1766 (Online) 
menjadi subjek penelitian berjumlah 9 orang guru pada indikator pengelolaan penggunaan (customization) yaitu sebesar $80,55 \%$ pada kriteria baik. Dapat disimpulkan dari data yang diperoleh, rata-rata guru yang menjadi subjek penelitian di SD Islam Al-Falah Jambi berpandangan baik pada indikator pengelolaan penggunaan (customization) pada aplikasi edmodo sebagai alat bantu kegiatan belajar.

Hasil penyebaran kuesioner persepsi guru terhadap aplikasi edmodo pada indikator penyajian informasi (content), persentase terendah dari persepsi guru yaitu sebesar $70,45 \%$ pada kriteria baik yang diperoleh oleh 1 orang guru. Persentase tertinggi dari peserpsi guru yaitu sebesar $84,09 \%$ pada kriteria baik oleh 3 orang guru. Selain itu, persepsi guru yang memperoleh persentase $81,81 \%$ pada kriteria baik sebanyak 1 orang guru, persepsi guru yang memperoleh persentase 79,54\% pada kriteria baik psebanyak 1 orang guru, persepsi guru yang memperoleh persentase $77,27 \%$ pada kriteria baik sebanyak 1 orang guru, persepsi guru yang memperoleh persentase $75 \%$ pada kriteria baik sebanyak 1 orang guru, dan persepsi guru yang memperoleh persentase $72,72 \%$ pada kriteria baik. Sebanyak 1 orang guru. Rata-rata persentase yang diperoleh dari keseluruhan guru SD Islam Al-Falah yang menjadi subjek penelitian berjumlah 9 orang guru pada indikator penyajian informasi (content) yaitu sebesar $78,78 \%$ pada kriteria baik. Dapat disimpulkan dari data yang diperoleh, rata-rata guru yang menjadi subjek penelitian di SD Islam Al-Falah Jambi berpandangan baik pada indikator penyajian informasi (content) pada aplikasi edmodo sebagai alat bantu kegiatan belajar.

Hasil penyebaran kuesioner persepsi guru terhadap aplikasi edmodo pada indikator kecepatan akses pada aplikasi (download delay), persentase terendah dari persepsi guru yaitu sebesar $75 \%$ pada kriteria baik yang diperoleh oleh 6 orang guru. Persentase tertinggi dari peserpsi guru yaitu sebesar $87,5 \%$ pada kriteria baik oleh 3 orang guru. Rata-rata persentase yang diperoleh dari keseluruhan guru SD Islam Al-Falah yang menjadi subjek penelitian berjumlah 9 orang guru pada indikator kecepatan akses pada aplikasi (download delay) yaitu sebesar $79,16 \%$ pada kriteria baik. Dapat disimpulkan dari data yang diperoleh, rata-rata guru yang menjadi subjek penelitian di SD Islam Al-Falah Jambi berpandangan baik pada indikator kecepatan akses pada aplikasi (download delay) pada aplikasi edmodo sebagai alat bantu kegiatan belajar.

Hasil penyebaran kuesioner persepsi guru terhadap aplikasi edmodo pada indikator kepuasan penggunaan (user satisfaction), persentase terendah dari persepsi guru yaitu sebesar $75 \%$ pada kriteria baik yang diperoleh oleh 4 orang guru. Persentase tertinggi dari peserpsi guru yaitu sebesar $100 \%$ pada kriteria sangat baik oleh 2 orang guru. Selain itu, persepsi guru yang memperoleh persentase $87,5 \%$ pada kriteria baik sebanyak 3 orang guru. Rata-rata persentase yang diperoleh dari keseluruhan guru SD Islam Al-Falah yang menjadi subjek penelitian berjumlah 9 orang guru pada indikator kepuasan penggunaan (user satisfaction) yaitu sebesar $84,72 \%$ pada kriteria baik. Dapat disimpulkan dari data yang diperoleh, rata-rata guru yang menjadi subjek penelitian di SD Islam Al-Falah Jambi berpandangan baik pada indikator kepuasan penggunaan (user satisfaction) pada aplikasi edmodo sebagai alat bantu kegiatan belajar.

\section{SIMPULAN}

Berdasarkan kelima indikator persepsi guru, diperoleh persentase rata-rata persepsi guru terhadap aplikasi edmodo sebagai alat bantu kegiatan belajar di SD Islam Al-Falah Jambi dari hasil penjumlahan persentase ratarata setiap indikator yaitu $81,451 \%$ pada kriteria baik. Hal tersebut dikarenakan persentase rata-ratanya $81,451 \%$ pada kriteria baik berdasarkan kategori kriteria yang telah ditetapkan pada penelitian ini. 
Dengan adanya gambaran atau deskripsi persepsi guru terhadap aplikasi edmodo sebagai alat bantu kegiatan belajar di SD Islam Al-Falah Jambi, hendaknya kepala sekolah dapat terus memfasilitasi dan memberikan dorongan kepada guru-guru untuk terus meningkatkan kompetensi pedagogik dalam pembelajaran. Guru hendaknya terus memperbanyak ilmu pengetahuan di era digitalisasi dan meningkatkan semua kompetensi-kompetensi yang harus dimiliki guru baik kompetensi profesional, pedagogik, sosial, dan kepribadian.

Bagi peserta didik hendaknya dapat memanfaatkan kecanggihan teknologi dalam hal positif seperti untuk kepentingan belajar dan mempermudah mendapatkan ilmu pengetahuan dimana pun dan kapan pun pada era digitalisasi saat ini. Dengan adanya kecanggihan teknologi yang dapat dimanfaatkan oleh guru dan peserta didik, seorang guru tetap mempunyai peran yang sangat penting untuk menjadi pendidik dimasa yang akan datang. Untuk penelitian selanjutnya diharapkan dapat menutuoi segala kekurangan pada penelitian ini yang berkaitan dengan peran aplikasi edmodo di sekolah dasar.

\section{DAFTAR PUSTAKA}

Basori. (2013). Pemanfaatan Social Learning Network "Edmodo" dalam Membantu Perkuliahan Teori Bodi Otomotif di Prodi PTM JPTK FKIP UNS. JIPTEK, VI(2), 99-105.

Kanca, I. N. (2018). Menjadi Guru Pendidikan Jasmani Olahraga dan Kesehatan di Abad 21. Prosiding Seminar Nasional IPTEK Olahraga, 21-27.

Lanusi, D. H. (2018). Penerapan Kelas Digital Edmodo Untuk Meningkatkan Minat Belajar dan Hasul Belajar Siswa. Dikdaktika Pendidikan Dasar, 2(1), 58-72.

Permendikbud. (2014). Permendikbud No. 110 Tahun 2014 Tentang Penyelenggaraan Pendidikan Jarak Jauh Jenjang Pendidikan
Dasar dan Menengah. Jakarta: Kementrian Pendidikan dan Kebudayaan

Sukono. (2018). Memanfaatkan Kemajuan Teknologi untuk Meningkatkan Kompetensi Guru. Prosiding Profesionalisme Guru Abad XXI, 59-64.

Sugiyono. (2013). Metode Penelitian Pendidikan Pendekatan Kuantitatif, Kualitatif, dan $R \& D$. Bandung: Alfabeta

Sugiyono. (2014). Metode Penelitian Pendidikan Pendekatan Kuantitatif, Kualitatif, dan $R \& D$. Bandung: Alfabeta

Sugiyono. (2015). Metode Penelitian Pendidikan Pendekatan Kuantitatif, Kualitatif, dan $R \& D$. Bandung: Alfabeta

Sugiyono. (2018). Metode Penelitian Pendidikan Pendekatan Kuantitatif, Kualitatif, dan $R \& D$. Bandung: Alfabeta

$$
\text { Copyright } \text { C2020, JRPD, ISSN } 2615 \text { - } 1723 \text { (Print), ISSN } 2615 \text { - } 1766 \text { (Online) }
$$

